\title{
Forseti
}

\section{La protección de los acreedores en la reducción del capital}

\author{
Jorge Ossio Gargurevich*
}

\begin{abstract}
Resumen.- De los artículos 218 y 219 de la Ley General de Sociedades se desprenden dos interpretaciones. Por un lado, dichas normas impedirían proceder con la reducción de capital hasta transcurrido el plazo de 30 días; mientras que por otro, impedirían la salida de la sociedad de los recursos equivalentes a la reducción del capital en tanto transcurra el plazo. El autor trata de resolver la disyuntiva entre ambas interpretaciones $y$ reconoce la necesidad de la protección a los acreedores.
\end{abstract}

Abstract.- From the articles 218 and 219 of the General Law of Business Corporations two interpretations can be identified. In one hand, these rules would prevent the capital reduction itself from taking place until the 30-day period has elapsed, while on the other hand, they would only prevent the company from leaving the resources equivalent to the amount of the capital reduction while the period expires. This article tries to resolve the dilemma between both interpretations. In addition, the author recognizes the need for an adequate protection of creditors. 


\section{Introducción}

El segundo párrafo del artículo 218 de la Ley General de Sociedades (LGS) establece que "cuando la reducción de capital importe devolución de aportes o la exención de dividendos pasivos o de cualquier otra cantidad adeudada por razón de los aportes, ella sólo puede llevarse a cabo luego de 30 días de la última publicación del aviso" respectivo.

Por su lado, el artículo 219 de la LGS señala que "el acreedor de la sociedad, aun cuando su crédito esté sujeto a condición o a plazo, tiene derecho de oponerse a la ejecución del acuerdo de reducción del capital si su crédito no se encuentra adecuadamente garantizado", dentro del plazo de 30 días mencionado en el párrafo anterior. Asimismo, esta norma agrega que, de producirse esta oposición, se suspende "la ejecución del acuerdo hasta que la sociedad pague los créditos o los garantice a satisfacción del juez".

Nos preguntamos si estas normas impiden proceder con el acto mismo de la reducción de capital hasta transcurrido el plazo de 30 días mencionado por el artículo 218 de la LGS antes referido, o si lo que buscan es simplemente impedir la salida de la sociedad de los recursos equivalentes al importe de la reducción del capital (o la compensación correspondiente en el caso de los dividendos pasivos adeudados a la sociedad y similares ${ }^{1}$ ) en tanto transcurra este plazo.

En esta segunda interpretación, la reducción del capital existiría como acto y generaría sus efectos al interior de la sociedad desde el momento del acuerdo mismo, es decir, básicamente la disminución del capital y la exclusión del respectivo accionista de su condición de tal, aunque el importe de la reducción sólo pueda ser pagado luego de los 30 días que menciona la norma.

En las siguientes líneas aportaremos algunas ideas para tratar de dar respuesta a esta interrogante.

\section{Comentario General}

Como anota Elías Laroza², en términos jurídicos el capital social es una cifra del pasivo de la sociedad que representa una deuda de la misma frente a sus socios, añadiendo que ello es así porque algún día, al ocurrir el cese de las

1 En adelante, y para mayor simplicidad de la exposición, sólo haremos referencia al caso de reducción del capital más común, es decir, aquél que importa la devolución de aportes al accionista beneficiado, y ya no a los otros casos mencionados en el segundo párrafo del artículo 218 de la LGS.

2 ELÍAS LAROZA, Enrique. Derecho Societario Peruano, Ley General de Sociedades. Edición puesta al día por el Estudio Rodrigo, Elías \& Medrano. Lima: Gaceta Jurídica, 2015, Tomo I, p. 161. 
operaciones, el mismo debe ser devuelto por la sociedad a éstos. Pero sin perjuicio de lo anterior, como este mismo autor anota ${ }^{3}$, el capital social representa también una garantía para los acreedores, desde que los activos de la sociedad respaldan, "con absoluta prioridad", el pago de los pasivos que la misma tenga con terceros antes que la devolución del capital a los socios 4 .

En efecto, los socios de la sociedad son, como ya se ha señalado, acreedores del importe del capital social, pero lo son en último orden de prelación, porque para que tal capital pueda ser devuelto a los socios, la sociedad tendría que haber pagado todas las deudas que tenga frente a terceros.

Justamente debido a esto último, se entiende la marcada preocupación del legislador por proteger, en menor o mayor medida, a los terceros acreedores de la sociedad en los casos de reducción del capital. La entrega del capital a los socios ciertamente implicará una disminución de la "garantía" que ese capital supone respecto al pago de las acreencias que tales terceros puedan tener contra esa sociedad.

Ampliando esta idea, el profesor español Jordá García señala que:

"es comúnmente aceptada la necesidad de proteger a los acreedores de las sociedades de capital cuando éstas reducen, precisamente, el capital social por la especial función de garantía que tradicionalmente se le ha otorgado y que se sustenta en la consideración de que el capital social, como componente fundamental del patrimonio neto, viene a significar la cifra de retención de activos en el balance y que favorece que dichos activos, al menos a valor contable, superen el montante de los pasivos exigibles contabilizados de forma que el pago de estos pudiera entenderse de alguna forma asegurado"5.

3 ELIAS LAROZA anota a este respecto que el capital social representa una garantía para los acreedores a pesar de constituir un pasivo de la sociedad, "simplemente por el singular mecanismo legal del pago de los pasivos de una sociedad", en la medida en que "respaldan, con absoluta prioridad, el pago de los pasivos que la empresa pueda tener en favor de terceros. En otras palabras, la sociedad no puede pagar su deuda por el capital a los socios mientras no haya terminado de pagar, previamente, todas las deudas que tenga frente a terceros".

ELÍAS LAROZA, Enrique. Derecho Societario Peruano, Ley General de Sociedades. Edición puesta al día por el Estudio Rodrigo, Elías \& Medrano. Lima: Gaceta Jurídica, 2015, Tomo I, p. 161.

4 Sobre este mismo tema, PRADES CUTILLAS, Daniel. (Fundamentos Jurídicos de la Actividad Empresarial. Civitas, Thomson Reuters, Editorial Aranzadi S.A., 2015, p. 436), señala que el "capital es pues tanto la chispa iniciadora de la actividad, pues financia la inversión necesaria para acometer el negocio con posibilidad de éxito, como la garantía aparente, para los acreedores, de hasta donde alcanza la asunción de riesgo por los socios".

5 JORDÁ GARCÍA, Rafael. "La protección de los acreedores en la reducción de capital de las sociedades de responsabilidad limitada en el Anteproyecto de Código mercantil". En Revista de Derecho Mercantil, N²97, Julio - Septiembre 2015, pp. 99 - 117. 
Algunas voces discrepantes, sin embargo, anotan que la verdadera garantía de los acreedores está en el patrimonio de la empresa, y que la cuenta capital es solo un elemento secundario cuando se hace la evaluación del respectivo financiamiento entregado a la sociedad ${ }^{6}$. Y en ese sentido, nos hacen ver que la escasa frecuencia con que los acreedores utilizan el mecanismo de oposición a las reducciones de capital, como también sucede en el Perú, demostraría que estas voces no carecen de razón?

En otro ángulo de análisis de esta misma problemática, Jordá García ${ }^{8}$ se pregunta si con el "exiguo capital social" que a veces se exige a algunas sociedades se puede asegurar que "se van a poder satisfacer todas las deudas sociales". Y esto nuevamente es particularmente cierto en el Perú, pues nuestra ley, en el caso general, no exige capital mínimo para la constitución de sociedades, lo que también podría demostrar que el mercado se detiene en el análisis del patrimonio, antes que en el de la cuenta capital, para determinar si sus créditos están adecuadamente garantizados o no.

Reforzando estos cuestionamientos a la función de garantía que cumple el capital, Escribano Gamir, citando a Portale, señala que desde "los últimos años de los sesenta del siglo pasado, se fue abriendo paso la corriente que, en réplica a la tradicional, erigiría la función empresarial de esta magnitud en la nueva base para comprender la 'misión básica' del capital. De este modo, se negaba la

6 PÉREZ DE LA CRUZ BLANCO, Antonio con la colaboración de Adolfo AURIOLES MARTIN (Comentario al Régimen de las Sociedades Mercantiles. Dirigido por Rodrigo URIA, Aurelio MENENDEZ y Manuel OLIVENCIA, Tomo VII, Modificación de Estatutos en la Sociedad Anónima y Reducción de Capital, Volumen N³, La Reducción de Capital, Editorial Civitas S.A., 1995, p. 93) anota sobre el particular lo siguiente: "Los detractores de este planteamiento, tan apegado a lo que siempre se ha llamado 'jurisprudencia de intereses', lo combaten, también dentro de esta misma línea metodológica, afirmando, no siempre sin razón, que a la hora de conceder crédito a una compañía anónima, la pura cifra de capital social es un elemento muy secundario para determinar la decisión del financiador. Este atenderá con preferencia a otras magnitudes contables, como es el saldo de la cuenta de pérdidas y ganancias de los últimos ejercicios, la composición del activo (pues existen elementos patrimoniales valorados ex ministerio legis, por cantidad muy inferior a su precio de presumible realización, lo que robustece considerablemente la solidez de la sociedad), el volumen de los llamados recursos propios que engloba, desde luego, al capital, pero con él a las reservas de todo orden, el coeficiente o ratio en que se hallan estos recursos con el total del pasivo exigible, así como la cadencia en los vencimientos de las deudas pendientes, etc. Todo ello, al margen de la solvencia comercial de la entidad asentada sobre la personalidad de sus gestores y la opinión que en el tráfico se tiene sobre la seriedad y puntualidad en el cumplimiento de sus obligaciones".

7 PÉREZ DE LA CRUZ BLANCO, Antonio. Comentario al Régimen de las Sociedades Mercantiles. Dirigido por Rodrigo URIA, Aurelio MENENDEZ y Manuel OLIVENCIA, Tomo VII Modificación de Estatutos en la Sociedad Anónima y Reducción de Capital, Volumen N³, La Reducción de Capital, Editorial Civitas S.A., 1995, p. 93.

8 JORDÁ GARCÍA, Rafael. "La protección de los acreedores en la reducción de capital de las sociedades de responsabilidad limitada en el Anteproyecto de Código mercantil". En Revista de Derecho Mercantil, N²97, Julio - Septiembre 2015, pp. 99 - 117. 
función garantística (al menos de modo directo) para afirmar que $<<$ el resultado útil que individualiza la función del capital y el logro del equilibrio económico-financiero de la empresa (adecuada relación entre 'medios propios' y medios de terceros, en el conjunto de todos los que necesita la sociedad para lograr el objeto social) (...) constituye la única y verdadera 'garantía' del pago de las deudas sociales $>>"$.

A pesar de estos cuestionamientos a la función de garantía que la doctrina tradicional siempre vio en el capital, Prades Cutillas nos indica que aún se da que los acreedores en muchos casos contratan con la sociedad confiados en que el capital es "la red de seguridad que garantiza a los terceros el cobro de sus créditos pues, si fuera necesario liquidar los activos, debería quedar limpio para su devolución a los socios tras satisfacer la totalidad de las obligaciones"10.

Al margen de las disquisiciones anteriores sobre la vigencia de la tesis tradicional que ve al capital como la única y verdadera garantía de los acreedores quirografarios para el pago de sus créditos y las teorías más modernas que cuestionan o complementan esto, lo cierto es que nadie discute que siguen siendo universalmente necesarios los mecanismos de protección a los acreedores en casos de reducción de capital con devolución de aportes a los $\operatorname{socios}^{11}$

\section{Tratamiento de la Protección de los Acreedores en la Reducción del Capital en otras Jurisdicciones}

\subsection{La Legislación Comparada}

En la evolución que han sufrido los sistemas de protección de acreedores en la reducción de capital Escribano Gamir ${ }^{12}$ nos habla de una primera etapa

9 ESCRIBANO GÁMIR, Rosario. "La Directiva 2006/68/CE, de 6 de septiembre, en materia de tutela de los derechos de crédito de los acreedores sociales frente a la reducción del capital social. Apuntes de una reforma anunciada". En Revista de Derecho de Sociedades, N²8, 2007, pp. 161-182.

10 PRADES CUTILLAS, Daniel. Fundamentos Jurídicos de la Actividad Empresarial. Civitas, Thomson Reuters, Editorial Aranzadi S.A., 2015, p. 437.

11 JORDÁ GARCÍA señala sobre este tema que sin "perjuicio de la crisis que, fundamentalmente por su limitado importe, sufre la figura del capital social como cifra de garantía de los acreedores, no ha perdido consistencia la necesidad de proteger la cifra del capital social en garantía de los acreedores"

JORDÁ GARCÍA, Rafael. "La protección de los acreedores en la reducción de capital de las sociedades de responsabilidad limitada en el Anteproyecto de Código mercantil". En Revista de Derecho Mercantil, N²97, Julio - Septiembre 2015, pp. 99 - 117.

12 ESCRIBANO GÁMIR, Rosario. "La Directiva 2006/68/CE, de 6 de septiembre, en materia de tutela de los derechos de crédito de los acreedores sociales frente a la reducción del capital 
enfocada no en la sociedad ('favor societatis') sino en los terceros, en que se impedía derogar o modificar las cláusulas contenidas en el estatuto en tanto afectaran a los intereses de éstos. Así la "ineficacia de los actos sociales que así lo hicieran se convertiría en el protocolo único de actuación". Agrega Escribano Gamir que en aras a la tesis del "derecho de prelación de los acreedores sociales sobre el patrimonio de la sociedad", lógicamente "se prohibiría a las sociedades realizar reducciones bajo cualquier signo; esto es, con independencia de la finalidad perseguida por la operación". Se nos dice también que estos sistemas estaban fuertemente enraizados en reglas de Derecho civil o común, desde que la evolución del Derecho mercantil estaba aún en ciernes.

Luego, esta misma autora señala que la "realidad del tráfico impondría el abandono de tan estricta postura y, así, aun sin renunciar a la aplicación de los principios del derecho civil, se tiende a revestir la señalada operación de fuertes restricciones". Continúa esta doctrina indicando que se opta entonces por permitir la reducción de capital, pero con soluciones que van desde blindar a los acreedores pre existentes de manera que debía seguir respetándose para ellos la cuantía originaria del capital para todos los efectos (Codice de Commercio italiano de 1882) hasta atribuir a los mismos "un derecho de satisfacción prioritario y preferente frente a cualquier reembolso a los socios"13.

Posteriormente, Escribano Gamir anota que, paulatinamente, aparecen en los distintos ordenamientos técnicas de tutela de los acreedores más próximas a la especialidad mercantil antes que al derecho común o civil, evolucionando a "un claro 'favor societatis', con el designio de permitir a la sociedad adoptar medidas que favorezcan su desarrollo, así como la racionalización de la empresa". Se agrega que las nuevas normas "no son sino el resultado de un continuo y gradual proceso de adecuación del Derecho a las estructuras económicas y sociales que lo explican y justifican; adecuación que, desde el cambio de mentalidad, acierta en la comprensión de que los intereses en juego de la sociedad y de sus acreedores no siempre entran en conflicto"14.

En esta etapa de la evolución de las normas sobre tutela de los acreedores en los casos de reducción de capital, abundante doctrina señala que los distintos

social. Apuntes de una reforma anunciada". En Revista de Derecho de Sociedades, N²8, 2007, pp. 161-182.

13 ESCRIBANO GÁMIR, Rosario. "La Directiva 2006/68/CE, de 6 de septiembre, en materia de tutela de los derechos de crédito de los acreedores sociales frente a la reducción del capital social. Apuntes de una reforma anunciada". En Revista de Derecho de Sociedades, ISSN 11347686, N 28, 2007, Editorial Aranzadi, S.A.U., pp. 161-182.

14 Ídem. 
sistemas de protección pueden clasificarse en sistemas de protección 'a priori' (que podríamos llamar "preventivos") y sistemas de protección 'a posteriori' (que podríamos llamar "reactivos").

\section{Los sistemas 'a priori' o preventivos}

De lo que se ha podido consultar parece que el sistema de protección de acreedores dominante es el sistema 'a priori', el cual básicamente consiste en dar a conocer a los acreedores el acuerdo o proyecto de reducción de capital "mediante su publicación, abriéndose, a continuación, un plazo que varía según los ordenamientos (entre uno y tres meses), durante el cual la operación se suspende y se insta a la sociedad deudora, básicamente, a prestar garantía o, en su caso, a satisfacer los créditos pendientes"15.

Dentro de las legislaciones que optan por el sistema de protección de acreedores 'a priori' o preventivo está la legislación española, en lo que se refiere a las sociedades anónimas, que en su etapa moderna va desde su antecedente más antiguo, la Ley de Sociedades Anónimas de 1951, hasta la actual Ley de Sociedades de Capital de 2010, pasando por la Ley de Sociedades Anónimas de 1989.

Así, el artículo 98 de la Ley de Sociedades Anónimas española de 1951 establecía que "ningún acuerdo de reducción de capital que implique restitución de sus aportaciones a los accionistas, o condonación de dividendos pasivos, podrá llevarse a efecto antes de que transcurra el plazo de tres meses" desde la última publicación que esa norma disponía. Durante ese plazo, "los acreedores ordinarios podrán oponerse a la ejecución del acuerdo de reducción si sus créditos no son satisfechos o la Sociedad no presta garantía", agregando la ley luego que será "nulo todo pago o liberación de dividendos pasivos que se realice antes de transcurrir el plazo de tres meses, o, a pesar de la oposición entablada".

La Ley de Sociedades Anónimas española de 1989 establecía en su artículo 166 que "los acreedores cuyos créditos hayan nacido antes de la fecha del último anuncio (...) no hayan vencido en ese momento y hasta que se les garanticen tales créditos tendrán el derecho de oponerse a la reducción". Esta norma agregaba luego que en "los casos en que los acreedores tengan derecho a oponerse a la reducción, ésta no podrá llevarse a efecto hasta que la sociedad preste garantía a satisfacción del acreedor o, en otro caso, hasta que notifique a dicho acreedor la prestación de fianza solidaria en favor de la sociedad (...) y hasta tanto no prescriba la acción para exigir su cumplimiento".

15 Ibid., p. 115. 
Por su lado, el artículo 334 de la Ley de Sociedades de Capital española de 2010 señala que "los acreedores de la sociedad anónima cuyos créditos hayan nacido antes de la fecha del último anuncio del acuerdo de reducción del capital, no hayan vencido en ese momento y hasta que se les garanticen tales créditos tendrán el derecho de oponerse a la reducción".

Luego, el artículo 337 de esta misma ley señala que, de ejercerse este derecho de oposición, "la reducción del capital no podrá llevarse a efecto hasta que la sociedad preste garantía a satisfacción del acreedor o, en otro caso, hasta que notifique a dicho acreedor la prestación de fianza solidaria en favor de la sociedad (...) por la cuantía del crédito" respectivo.

En la legislación mexicana también hay protección 'a priori' de los acreedores, pues el artículo 9 de su Ley General de Sociedades Mercantiles establece que los acreedores de la sociedad pueden oponerse a una reducción de capital ante la autoridad judicial hasta cinco días después de la última de las publicaciones que esta misma norma dispone, "suspendiéndose la reducción entre tanto la sociedad no pague los créditos de los opositores, o no los garantice a satisfacción del Juez que conozca del asunto, o hasta que cause ejecutoria la sentencia que declare que la oposición es infundada".

Dentro de las legislaciones que acogen sistemas de protección a los acreedores preventivos, pero distintos al clásico de la posible oposición y suspensión del proceso de reducción de capital, podemos mencionar a la legislación francesa, que en el Artículo L 225-205 de su Código de Comercio señala que cuando la junta apruebe "un proyecto de reducción del capital no motivada por pérdidas", los acreedores cuyos créditos sean anteriores podrán impugnar la reducción, en el plazo respectivo. Esta norma agrega luego que si hay impugnación, la misma se tramitará judicialmente pudiendo el juez rechazarla "o, por el contrario, ordenará, o bien el reembolso de los créditos, o bien la constitución de garantías si la sociedad las ofrece y si son consideradas como suficientes".

Según esta norma del Código de Comercio francés, las "operaciones de reducción de capital no podrán iniciarse durante el periodo de impugnación ni, en su caso, antes de que se haya resuelto en primera instancia sobre dicha impugnación".

Como se ve, el sistema francés concede un papel relevante a los tribunales, pues la impugnación de la reducción de capital por algún acreedor puede eventualmente ser rechazada por el juez, lo que constituye una novedad, pues en las legislaciones que hemos examinado antes la oposición de los acreedores implica la suspensión cuasiautomática del proceso de reducción de capital. 
Otra legislación que se apartó de las teorías clásicas de protección a los acreedores en la reducción de capital y que también concede un papel relevante a los tribunales en esta materia es la legislación inglesa ${ }^{16}$. Así, el artículo 645 de la "Companies Act" de 2006 establece que en una reducción de capital con devolución de aportes a los accionistas la sociedad puede acudir a la corte para que la misma confirme la reducción y disponga que no procede el derecho de objeción de los acreedores respecto de esa reducción.

De no ser este el caso, el artículo 646 de esta misma norma señala que cualquier acreedor que al momento que establezca la corte es titular de un crédito a cargo de la sociedad y puede probar que hay una posibilidad cierta de que la reducción implicará que la sociedad no sea capaz de pagar la deuda cuando ésta venza, tendrá el derecho de objetar la reducción de capital. Este artículo agrega que para efectos de lo anterior, la corte debe aprobar una lista de todos los deudores a los que les pueda corresponder este derecho de objetar la reducción de capital en los términos recién expuestos.

El artículo 647 de la "Companies Act" complementa lo anterior señalando que para que proceda la reducción de capital la Corte debe confirmarla y que solo podrá hacerlo si ha obtenido el consentimiento de todos los acreedores con derecho a objetar la reducción de capital de acuerdo a la lista a la que se refiere el artículo anterior, o los respectivos créditos han sido pagados o garantizados.

Como se ve, también en esta legislación el papel tutelar de los jueces para proteger a los acreedores en las reducciones de capital es fundamental. ${ }^{17}$

16 La solución particular del derecho inglés data de hace más de 200 años, en realidad. Sobre este tema, ESCRIBANO GAMIR nos dice que en "giro sorprendente para el pensamiento jurídico de la época", la Companies Act inglesa de 1867 (Sect 9) "optaría por apartarse de las tesis dominantes -fuertemente apegadas al Derecho Común- y someter la reducción al juicio de la Magistratura. Ésta debía pronunciarse sobre la oportunidad de la operación y el peligro que pudiera suponer para los acreedores sociales.

ESCRIBANO GÁMIR, Rosario. "La Directiva 2006/68/CE, de 6 de septiembre, en materia de tutela de los derechos de crédito de los acreedores sociales frente a la reducción del capital social. Apuntes de una reforma anunciada". En Revista de Derecho de Sociedades, No28, 2007, pp. 161-182.

17 Escribano Gámir critica el sistema inglés, que en sus aspectos esenciales ya venía desde la Companies Act de 1867, señalando que a "decir verdad, y como reflejaría algunos años después alguna muestra europea, el recurso a la autoridad (administrativa o judicial) intentaría remediar la incapacidad del cuerpo de la doctrina científica y jurisprudencial de solventar los problemas con los que jurídicamente se encontraba para dar respuesta a las necesidades de la práctica mercantil (cada vez más extendida y con fuerte presión), sorteando los implacables dictados del Derecho Común; garantía y seguridad de la ordenación de los Estados (algunos de ellos de unificación reciente). Este recurso, empero, no cosecharía buenos resultados. Por un lado, la intervención pública no suplía el gravísimo inconveniente que suponía exigir el consentimiento de los acreedores para permitir a las sociedades reducir su capital; por otro, no constituía una alternativa mejor a las soluciones ofrecidas por el Derecho Común, toda vez que constituía una tutela extremadamente 
Otro sistema preventivo de protección de acreedores de características particulares es el consagrado por el artículo 244 del Capítulo 1 ("GENERAL CORPORATION LAW") del Título 8 ("Corporations") de "The Delaware Code" del Estado de Delaware de los Estados Unidos de América, que establece que no cabe la reducción del capital a menos que los activos de la sociedad remanentes luego de la reducción sean suficientes para pagar todas las deudas no garantizadas de la sociedad.

\section{Los sistemas 'a posteriori' o reactivos}

Dentro de las legislaciones que optan por sistemas de protección 'a posteriori', sistemas que, como ya hemos dicho, llamamos reactivos por oposición a los preventivos, podemos mencionar en primer lugar a la Ley de Sociedades de Capital española en lo que se refiere esta vez a las sociedades de responsabilidad limitada ${ }^{18}$, dado que el artículo 331 de la misma establece que en los casos de reducción de capital los socios a quienes se hubiera devuelto el valor de sus aportes "responderán solidariamente entre sí y con la sociedad del pago de las deudas sociales contraídas con anterioridad a la fecha en la que la reducción fuera oponible a terceros".

Siendo una regla de protección más dura que la que contempla esta ley en el caso de sociedades anónimas, claramente califica dentro de los sistemas de protección 'a posteriori', pues la consecuencia establecida por la ley exige que la reducción de capital exista primero como acto consumado. Al final, entonces, el sistema español de protección a los acreedores en casos de reducción de capital viene a ser uno mixto, preventivo en el caso de las sociedades anónimas y reactivo, en el caso de las sociedades de responsabilidad limitada (por lo menos en el caso general ${ }^{19}$ ).

enérgica, con el serio inconveniente de generar una ficticia confianza en los acreedores de la sociedad".

ESCRIBANO GÁMIR, Rosario. "La Directiva 2006/68/CE, de 6 de septiembre, en materia de tutela de los derechos de crédito de los acreedores sociales frente a la reducción del capital social. Apuntes de una reforma anunciada". En Revista de Derecho de Sociedades, N²8, 2007, pp. 161-182.

18 Ya hemos visto que en lo que se refiere a las sociedades anónimas, la legislación española se adscribe al sistema 'a priori' o preventivo.

19 En efecto, el artículo 333 de la Ley de Sociedades de Capital señala también que en las sociedades de responsabilidad limitada "los estatutos podrán establecer que ningún acuerdo de reducción del capital que implique restitución de sus aportaciones a los socios pueda llevarse a efecto sin que transcurra un plazo de tres meses a contar desde la fecha que se haya notificado a los acreedores", con objeto de que durante dicho plazo tales acreedores puedan "oponerse a la ejecución del acuerdo de reducción, si sus créditos no son satisfechos o la sociedad no preste garantía". Este mismo artículo agrega que "será nula toda restitución que se realice antes de transcurrir el plazo de tres meses o a pesar de la oposición entablada" Como se ve, la regla alternativa para las sociedades de responsabilidad limitada sí califica dentro de los sistemas de protección 'a priori' o preventivos. 
Otra de las legislaciones que optan por sistemas de protección 'a posteriori' es la Portuguesa, cuya Ley de Sociedades Comerciales (artículo 96), señala que dentro del mes posterior a la publicación de una reducción de capital (ya producida) cualquier acreedor puede acudir al poder judicial para que se prohíba a la respectiva sociedad cualquier distribución de reservas o utilidades durante un plazo que definirá el juez, a menos que la respectiva deuda del acreedor sea totalmente pagada, de encontrarse vencida, o garantizada de manera adecuada de no estarlo ${ }^{20}$.

Pero, según Escribano Gámir21, el máximo representante de este sistema de protección 'a posteriori' es el legislador alemán quien, en el artículo 224 de la Ley de Sociedades por Acciones, ha establecido que "la tutela de los derechos de los acreedores no paraliza la reducción, de forma tal que, tras la notificación del acuerdo pertinente al RM por parte de la Dirección y del Presidente del Consejo de Vigilancia de la sociedad, se producirá la inscripción de aquél y quedará efectivamente reducido el capital social". En ese sentido, el artículo 224 de la Ley de Sociedades por Acciones alemana señala que la reducción de capital surtirá efectos apenas se complete el registro de ese acto en el Registro Público.

Sin perjuicio de ello, sin embargo, el artículo 225 de esa Ley establece un mecanismo de protección a los acreedores conforme al cual los acreedores existentes antes de la publicación de la inscripción de la reducción de capital en el Registro Público podrán, dentro de los seis meses posteriores a esa publicación, solicitar garantías para el pago de sus créditos, agregándose que el pago del importe de la reducción del capital, por más que existe como acto jurídico, sólo podrá efectuarse luego de transcurridos los referidos seis meses y luego de que los acreedores que hayan ejercido sus derechos dentro de ese plazo sean adecuadamente garantizados o liquidados 22 .

20 Explicando este sistema, Jordá García señala que el "derecho portugués prevé (...) el registro y publicidad de la operación de reducción con la finalidad de darla a conocer a los acreedores sociales, permitiendo a éstos, para asegurar sus créditos, impedir o dificultar la posterior distribución de bienes por la sociedad, sin necesidad de intervención judicial previa".

JORDÁ GARCÍA, Rafael. "La protección de los acreedores en la reducción de capital de las sociedades de responsabilidad limitada en el Anteproyecto de Código mercantil". En Revista de Derecho Mercantil, N²97, Julio - Septiembre 2015.

21 ESCRIBANO GÁMIR, Rosario. La Protección de los Acreedores Sociales frente a la Reducción del Capital Social y a las Modificaciones Estructurales de las Sociedades Anónimas. Aranzadi Editorial, 1998, p. 134 y 199.

22 Ver comentario coincidente de VELASCO ALONSO sobre el sistema alemán de protección de acreedores en los casos de reducción de capital.

VELASCO ALONSO, Ángel. La Ley de Sociedades Anónimas. Madrid: Editoriales de Derecho Reunidas S.A., Quinta Edición, 1982, p. 534. 
Es interesante mencionar, como señala Escribano Gámirir2, que en opinión de algunos autores el sistema alemán representa "el estadio más evolucionado de las formas de defensa de los derechos crediticios, pues se conjuga esta finalidad con la de asegurar la realización" de la reducción de capital misma.

Finalmente, en la Ley de Sociedades Anónimas chilena se establece (artículo 28) que "no podrá procederse al reparto o devolución de capital (...) sino transcurridos treinta días desde la fecha de publicación en el Diario Oficial del extracto de la respectiva modificación".

\section{La Comunidad Europea}

En cuanto al sistema que impulsa la Comunidad Europea, la Directiva 1976/91/CE del Consejo estableció en el numeral 1 de su artículo 32 que en caso de reducción del capital, los "acreedores cuyos créditos se hubieren originado antes de la publicación de la decisión de la reducción tendrán al menos el derecho a obtener una garantía por los créditos aún no vencidos en el momento de esta publicación". Agrega este numeral que las "legislaciones de los Estados miembros fijarán las condiciones para el ejercicio de este derecho y no podrán excluir este derecho más que cuando el acreedor disponga de garantías adecuadas o éstas no sean necesarias teniendo en cuenta el patrimonio de la sociedad".

Por su lado, el numeral 2 de esta Directiva estableció, además, que "las legislaciones de los Estados miembros preverán al menos que la reducción no producirá efectos, o que no se podrá efectuar ningún pago en beneficio de accionistas, en tanto los acreedores no hubieran obtenido satisfacción o que un Tribunal hubiera decidido que no había lugar a acceder a su petición".

La técnica tuitiva propugnada por esta norma comunitaria consistía esencialmente entonces en reconocer en favor de los acreedores una garantía para el pago de sus créditos.

La Directiva 2006/68/CE del Parlamento Europeo y del Consejo modifica el numeral 1 del artículo 32 de la Directiva 1976/91/CE, básicamente incluyendo un segundo párrafo conforme al cual "en cualquier caso, los Estados miembros deberán garantizar que los acreedores están autorizados a dirigirse a la autoridad administrativa o judicial competente para obtener las garantías adecuadas, siempre que puedan demostrar, de forma creíble, que debido a esta reducción del capital suscrito la satisfacción de sus derechos está en juego y

23 ESCRIBANO GÁMIR, Rosario. La Protección de los Acreedores Sociales frente a la Reducción del Capital Social y a las Modificaciones Estructurales de las Sociedades Anónimas. Aranzadi Editorial, 1998, p. 134 
que no han obtenido las garantías adecuadas de la sociedad".

Muy recientemente la Directiva (UE) 2017/1132 del Parlamento Europeo y del Consejo de 14 de junio de 2017 ha procedido a codificar diversas Directivas anteriores sobre algunos aspectos del Derecho de sociedades, y en ese sentido ha aprobado en su Sección 5 un texto unificado y ordenado de normas sobre el aumento y la reducción de capital. Pues bien, en su artículo 75, puntualmente referido a las "Garantías para los acreedores en caso de reducción del capital suscrito", ha consagrado una norma que esencialmente repite de manera ordenada las normas que ya consagraban la Directiva 1976/91/CE y la Directiva 2006/68/CE a las que hemos hecho referencia en los párrafos anteriores.

Conforme a todo esto, entonces, vemos que la Comunidad Europea propugna ahora que sus Estados Miembros aprueben legislaciones de tutela en favor de los acreedores en los casos de reducción de capital que exijan la prueba del perjuicio como requisito necesario para obtener protección ${ }^{24}$.

Es posible entonces que en los subsiguientes años veamos, esencialmente en las legislaciones europeas, variaciones para aproximar el sistema de protección de acreedores en los casos de reducción de capital a este requisito. Y de hecho, Jordá García ${ }^{25}$ ya nos advierte que en España el Anteproyecto de Código mercantil, introduce algunas novedades significativas, "al exigir a los acreedores, para oponerse a la reducción, justificar que la situación patrimonial de la sociedad que reduce capital pone con ello en riesgo la satisfacción de sus créditos".

Sin perjuicio de lo anterior, es interesante observar que el numeral 2 de la Directiva 1976/91/CE citada antes en este acápite admite que la protección a los acreedores se da, con igual eficacia, en legislaciones que optan por suspender los efectos de la reducción de capital en tanto transcurra el plazo de oposición respectivo, así como en sistemas que optan por simplemente postergar el pago del importe de la reducción a los accionistas en tanto los acreedores no hubieran obtenido satisfacción. Esta norma, como ya hemos

24 Sobre este particular ESCRIBANO GÁMIR señala que verdaderamente "es en este elemento donde hallamos la novedad del nuevo sistema. El perjuicio patrimonial se erige, de este modo, en clave del sistema tuitivo de acreedores. A resultas pues de la reforma operada, las legislaciones nacionales deben ordenar sus sistemas sobre la base de este requisito"

ESCRIBANO GÁMIR, Rosario. "La Directiva 2006/68/CE, de 6 de septiembre, en materia de tutela de los derechos de crédito de los acreedores sociales frente a la reducción del capital social. Apuntes de una reforma anunciada". En Revista de Derecho de Sociedades, No28, 2007, pp. 161-182.

25 JORDÁ GARCÍA, Rafael. "La protección de los acreedores en la reducción de capital de las sociedades de responsabilidad limitada en el Anteproyecto de Código mercantil". En Revista de Derecho Mercantil, N²97, Julio - Septiembre 2015, pp. 99 - 117. 
dicho, está nuevamente consagrada de manera expresa y con ese mismo texto en la recientísima Directiva (UE) 2017/113226.

\section{2. ¿La reducción del capital existe como acto en estas legislaciones?}

Creemos que no existe duda de que en el sistema español, en lo que se refiere a las sociedades de responsabilidad limitada, así como en el sistema portugués y en el sistema alemán, la reducción de capital existe como acto y genera todos sus efectos en base a los acuerdos respectivos y conforme a los requerimientos esenciales y formales que esas legislaciones puedan establecer para que ese acto opere legalmente, independientemente de las regulaciones sobre protección a los acreedores que esas legislaciones contemplan.

En todas estas legislaciones esas medidas de protección a los acreedores en situaciones de reducción de capital son reactivas, en el sentido de que responden a la existencia de la reducción de capital ya producida. En el caso de la legislación española para sociedades de responsabilidad limitada (caso general) la reducción de capital existe como acto pero genera responsabilidad solidaria frente a los acreedores entre los socios a los que se hubiera devuelto el valor de sus aportes. En el caso de la legislación portuguesa, luego de la reducción de capital consumada, se permite al acreedor solicitar que se prohíban temporalmente las distribuciones de reservas o utilidades a menos que el acreedor sea compensado o garantizado. Finalmente, en la legislación alemana los acreedores no solo podrán solicitar garantías para el pago de sus créditos dentro de un plazo de seis meses de ocurrida la reducción de capital, con todos sus efectos de fondo, sino que el pago del importe de la misma sólo podrá efectuarse luego de transcurrido ese plazo y luego de que los respectivos acreedores sean adecuadamente garantizados o liquidados.

En la legislación chilena también da la impresión de que no se pretendiese impedir los efectos de la reducción de capital como acto sino impedir solamente "el reparto o devolución de capital" hasta transcurrido el plazo que señala el artículo 28 de la Ley de Sociedades Anónimas.

Por su lado, parece claro que en los sistemas preventivos que optan por la tutela judicial o administrativa de la reducción de capital, no hay reducción de capital hasta emitida la resolución judicial o administrativa respectiva. Claramente es el caso en el sistema inglés en que la reducción de capital solo

26 En efecto, el numeral 2 del artículo 75 de esa Directiva (UE) 2017/1132 señala que "las legislaciones de los Estados miembros preverán al menos que la reducción no producirá efectos, o que no se podrá efectuar ningún pago en beneficio de los accionistas, en tanto que los acreedores no hubieran obtenido satisfacción o que un tribunal hubiera decidido que no había lugar a acceder a su petición". 
procede si la Corte la confirma, cosa que podrá ocurrir solo si se ha obtenido el consentimiento de todos los acreedores con derecho a objetar la reducción de capital o los respectivos créditos han sido pagados o garantizados.

También es el caso del sistema francés, en que la junta inicialmente aprueba solo un "proyecto de reducción de capital", para proceder con el verdadero proceso después de un posible tamiz judicial ante una eventual oposición de acreedores. Además el Código de Comercio francés es bastante claro al señalar que las operaciones de reducción de capital no podrán iniciarse durante el periodo de impugnación ni, de haber impugnación, antes de que se haya resuelto en primera instancia sobre la misma.

La legislación comunitaria parecería también encaminada en esa dirección pues ya hemos visto que la Directiva 2006 / 68 / CE del Parlamento Europeo y del Consejo, como nos dice Jordá García27, viene a "exigir en materia de derecho de oposición de los acreedores su tutela por una autoridad judicial o, en su caso, administrativa"28. Sin olvidar sin embargo, agregamos nosotros, que esta tutela jurisdiccional pasa por el tamiz de que el acreedor demuestre previamente el daño efectivo que podría estarle causando la reducción de

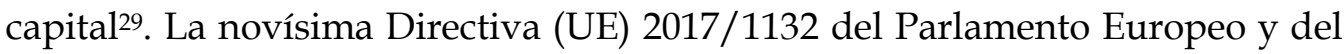
Consejo confirma este tratamiento, como ya hemos visto.

Pero, ¿qué sucede en el resto de legislaciones que optan por otros sistemas preventivos de protección de acreedores? ¿Será que, en oposición justamente a lo que sucede en sistemas 'a posteriori', como el portugués o el alemán, la reducción de capital no existe como acto hasta que se completen los plazos de oposición y demás requisitos que las legislaciones que los contemplan establecen? ¿Es así de claro?

Examinemos el tema a la luz básicamente de la legislación española de las sociedades anónimas, por ser de alguna manera similar a lo que señala la ley peruana sobre el tema, y contar con doctrina que nos puede ayudar en ese camino.

Diremos antes, sin embargo, que en relación a las otras legislaciones que se han mencionado es difícil para nosotros fijar una posición pues se trata de normas que no conocemos suficientemente. Así, en México se habla de una

27 JORDÁ GARCÍA, Rafael. "La protección de los acreedores en la reducción de capital de las sociedades de responsabilidad limitada en el Anteproyecto de Código mercantil". En Revista de Derecho Mercantil, №297, Julio - Septiembre 2015, pp. 99 - 117.

$28 \mathrm{Y}$, en efecto, esa norma señala que los Estados miembros "deberán garantizar que los acreedores están autorizados a dirigirse a la autoridad administrativa o judicial competente para obtener las garantías adecuadas" en casos de reducción de capital.

29 Ver sobre el particular La Directiva 2006/68/CE del Parlamento Europeo y del Consejo. 
"suspensión de la reducción"30 en tanto, básicamente, no se paguen o garanticen los respectivos créditos. Pero cabe la pregunta de si en el ínterin, antes de la oposición, el acto de reducción de capital tuvo efectos o no.

Por su lado, la legislación del Estado de Delaware impide que se adopte un acuerdo de reducción del capital a menos que los activos de la sociedad remanentes luego de la reducción sean suficientes para pagar todas las deudas no garantizadas de la sociedad. Allí sí es indudable que no debiera haber reducción de capital si no se cumple el pre requisito que la ley impone para ello. Pero siempre será válida la pregunta de cómo resuelve esa legislación aquellas situaciones en que sin cumplirse ese pre requisito la sociedad igual adopta un acuerdo de reducción de capital.

\section{La legislación española}

Regresando ahora al análisis que anunciamos de lo que establece sobre el tema la legislación española, hay que notar en primer lugar que, en el caso de las sociedades anónimas, existe obligación de publicar un anuncio sobre la reducción de capital que permite a los acreedores de la sociedad "oponerse a la reducción". El efecto de esta oposición es que "la reducción no podrá llevarse a efecto" hasta que el pago de los créditos respectivos esté suficientemente garantizado (artículo 337 de la Ley de Sociedades de Capital).

Como se puede apreciar el tratamiento de protección a los acreedores de las sociedades anónimas en la legislación española es muy similar al que consagra nuestra LGS en sus artículos 218 y 21931.

Ahora bien, la pregunta planteada en esta líneas, como se recuerda, es si adoptado válidamente el acuerdo de reducción de capital el mismo existe como acto y genera sus efectos al interior de la sociedad desde el momento del acuerdo mismo, o, más bien, que solo existe como acto y surte efectos jurídicos, en el mejor de los casos, desde el momento en que vence el plazo de oposición que consagra la ley en beneficio de los acreedores, es decir, en el caso de la legislación española, luego de vencido el mes posterior al "último anuncio del acuerdo" mencionado en el artículo 336 de la Ley de Sociedades de Capital.

Como acabamos de ver, la ley española anota que de producirse la oposición de algún acreedor dentro del plazo legal respectivo, "la reducción no podrá llevarse a efecto" hasta que el pago de los créditos respectivos esté

30 El texto exacto del artículo 9 de la Ley General de Sociedades Mercantiles mexicana dice, en realidad, "suspendiéndose la reducción".

31 Nuestra ley también señala que la reducción de capital "solo puede llevarse a cabo" luego de transcurrido el plazo de ley. 
suficientemente garantizado.

La doctrina española tiene opiniones dispares sobre la correcta interpretación de estas normas y sus antecedentes, la Ley de Sociedades Anónimas de 1951 y la Ley de Sociedades Anónimas de 1989.

Comentando el artículo 98 de la Ley de Sociedades Anónimas de $1951^{32}$ Velasco Alonso señala que el sistema de protección de acreedores que consagra esta norma implica que "el acuerdo quedará en suspenso: a) Durante el tiempo de publicación de los anuncios. b) Durante los tres meses siguientes a la fecha de publicación del último anuncio. c) Durante todo el tiempo que dure la oposición de cualquier acreedor entablada en tiempo y forma".

De este comentario parece desprenderse que el acuerdo de reducción de capital queda en suspenso desde el mismo momento en que se aprueba, con lo cual no surte efectos desde el día 1. Ese parece ser el efecto lógico según este comentario si hay suspensión "durante el tiempo de publicación de los anuncios".

Sin embargo, si tomamos en cuenta lo que nos dicen Garrigues Y Uría ${ }^{33}$ sobre este mismo artículo de la Ley de Sociedades Anónimas de 1951, ya no queda tan claro el tema. En efecto, según estos autores el sistema de protección de acreedores que consagra esta ley, implica "que el acuerdo de reducción no puede llevarse a efecto antes de que transcurra el plazo de oposición de los tres meses; de donde se desprende que no debe realizarse ningún pago a los accionistas ni ningún acto de liberación de dividendos pasivos antes de que transcurra ese plazo".

Como se ve, estos autores parecen señalar que el hecho de que el acuerdo de reducción de capital no pueda "llevarse a efecto antes de que transcurra el plazo de oposición" no implica que no exista la reducción de capital como acto jurídico, sino solo que "no deba realizarse ningún pago a los accionistas" en ese lapso.

La posición de estos autores parece verse más clara aun cuando explican los

32 Como se recuerda, el artículo 98 de la Ley de Sociedades Anónimas española de 1951 establecía que "ningún acuerdo de reducción de capital que implique restitución de sus aportaciones a los accionistas, o condonación de dividendos pasivos, podrá llevarse a efecto antes de que transcurra el plazo de tres meses" desde la última publicación que esa norma disponía. Durante ese plazo, "los acreedores ordinarios podrán oponerse a la ejecución del acuerdo de reducción si sus créditos no son satisfechos o la Sociedad no presta garantía", agregando la ley luego que será "nulo todo pago o liberación de dividendos pasivos que se realice antes de transcurrir el plazo de tres meses, o, a pesar de la oposición entablada".

33 GARRIGUES, Joaquín y URÍA, Rodrigo. Comentarios a la Ley de Sociedades Anónimas. Madrid: Imprenta Aguirre, Tercera Edición, Tomo II, 1976, p. 342. 
efectos de la nulidad de los pagos ${ }^{34}$ que se hagan en contravención de esa norma y señalan que esa nulidad afecta a "todo pago (...) que se realice antes de transcurrir el plazo de tres meses o a pesar de la oposición entablada en tiempo y forma por cualquier acreedor", para agregar después que la nulidad "supone que el accionista está obligado a devolver a la sociedad las cantidades que en concepto de restitución de sus aportaciones haya realizado aquella infringiendo el mandato de suspensión de ejecución del acuerdo de reducción".

Como se puede ver, estos autores no señalan que la nulidad que sanciona el artículo 98 la Ley de Sociedades Anónimas de 1951 afecte el acto de reducción de capital mismo sino a "todo pago" efectuado en relación a tal reducción. Parecería, entonces, que para estos autores el acuerdo de reducción de capital produce efectos jurídicos y lo que se suspende es únicamente la obligación patrimonial que surge del mismo.

Hay discusión en doctrina española, también, respecto al tratamiento de la protección a los acreedores en los casos de reducción de capital en la Ley de Sociedades Anónimas de 1989 y en la Ley de Sociedades de Capital de 2010³.

Escribano Gamir ${ }^{36}$ señala que la "suspensión" que acarrea la oposición de acreedores en los casos de reducción de capital "alcanza a la reducción como un todo, no pudiendo tratarse sin más de una ineficacia relativa del acuerdo. En efecto, téngase en cuenta que la citada operación entraña una alteración del originario programa societario que puede perjudicar a los acreedores sociales. Así aun cuando no se proponga una enumeración exhaustiva, el alcance objetivo del efecto paralizante comprenderá todos aquellos actos a través de

34 Ver texto de la norma en Nota al Pie de Página 32.

35 Como se recuerda, la Ley de Sociedades Anónimas de 1989 establecía en su artículo 166 que "los acreedores cuyos créditos hayan nacido antes de la fecha del último anuncio (...) no hayan vencido en ese momento y hasta que se les garanticen tales créditos tendrán el derecho de oponerse a la reducción". Esta norma agregaba luego que en "los casos en que los acreedores tengan derecho a oponerse a la reducción, ésta no podrá llevarse a efecto hasta que la sociedad preste garantía a satisfacción del acreedor o, en otro caso, hasta que notifique a dicho acreedor la prestación de fianza solidaria en favor de la sociedad (...) y hasta tanto no prescriba la acción para exigir su cumplimiento".

Por su lado, el artículo 334 de la Ley de Sociedades de Capital de 2010 señala que "los acreedores de la sociedad anónima cuyos créditos hayan nacido antes de la fecha del último anuncio del acuerdo de reducción del capital, no hayan vencido en ese momento y hasta que se les garanticen tales créditos tendrán el derecho de oponerse a la reducción". Luego, el artículo 337 de esta misma ley señala que, de ejercerse este derecho de oposición, "la reducción del capital no podrá llevarse a efecto hasta que la sociedad preste garantía a satisfacción del acreedor o, en otro caso, hasta que notifique a dicho acreedor la prestación de fianza solidaria en favor de la sociedad (...) por la cuantía del crédito" respectivo.

36 ESCRIBANO GÁMIR, Rosario. La Protección de los Acreedores Sociales frente a la Reducción del Capital Social y a las Modificaciones Estructurales de las Sociedades Anónimas. Aranzadi Editorial, 1998, pp. 411-412. 
los cuales la sociedad pretenda restituir aportaciones a los accionistas (...)". Esta autora agrega que "la reserva legal, la medida de las participaciones sociales, los derechos a ellas conexos y el límite máximo de emisión de obligaciones deberá calcularse sobre la base del capital anterior al acuerdo de reducción".

La posición de esta autora es clara, entonces, en cuanto a que no existe la reducción de capital como acto, y consecuentemente no produce ningún efecto legal, por lo menos hasta que venza el plazo de oposición de los acreedores.

En el mismo sentido, Rojo Y Beltrán ${ }^{37}$ señalan que el derecho de oposición "constituye un instrumento de tutela de los derechos de los acreedores de carácter preventivo, pues funciona 'a priori', impidiendo que el acto jurídico que puede causarles perjuicio (la reducción efectiva del capital social) llegue a producir efectos". Luego estos autores agregan que aunque "no se mencione expresamente, la oposición produce una suspensión plena del acuerdo, que afecta, no solo a la inscripción del mismo [...], sino a todos los actos jurídicos que derivarían de la plena efectividad del acuerdo: no pueden restituirse aportaciones, ni siquiera a modo de anticipo; no es posible cancelar dividendos pasivos contra la cuenta de capital; o la función organizativa del capital social (quórum y mayorías, porcentaje de reservas, etc.) sigue calculándose sobre la cifra de capital existente en el momento del acuerdo (sin tener en cuenta ninguna reducción)".

Acá también es claro que para este autor la reducción de capital tampoco produce ningún efecto legal hasta atendido el interés de los acreedores.

Sin embargo, y en contra de esta posición, otra autorizada doctrina española ${ }^{38}$ señala que "la formulación de la oposición comporta, como efecto más destacable, la paralización de la ejecución del acuerdo, hasta tanto se tomen la medidas conducentes a dar satisfacción a los derechos del acreedor que la haya entablado (no carece de sentido afirmar, entonces, que el derecho de oposición encubre realmente un derecho a suspender la ejecución del acuerdo de reducción, pero no a impedir que la reducción se lleve a cabo...)"39.

37 ROJO, Ángel y BELTRÁN, Emilio. Comentarios de la Ley de Sociedades de Capital. Civitas, Thomson Reuters, Tomo II, 2011, p. 2,429.

38 PÉREZ DE LA CRUZ BLANCO, Antonio. Comentario al Régimen de las Sociedades Mercantiles. Dirigido por Rodrigo URIA, Aurelio MENENDEZ y Manuel OLIVENCIA, Editorial Civitas S.A., Tomo VII Modificación de Estatutos en la Sociedad Anónima y Reducción de Capital, Volumen N³, La Reducción de Capital, 1995, p. 109.

39 Como se ha indicado, este autor comenta la Ley de Sociedades Anónimas española y no la Ley de Sociedades de Capital, que es la que hemos venido citando anteriormente. Sin embargo, el texto de la Ley de Sociedades Anónimas, en su artículo 166, es similar al de los 
Como se puede ver, del paréntesis final de este comentario parece desprenderse que esta "paralización de la ejecución del acuerdo" que conlleva la oposición de algún acreedor en la legislación española no hace a Pérez De la Cruz cuestionar la existencia de la reducción de capital como acto jurídico con efectos plenos desde la adopción del respectivo acuerdo, sino solo lo lleva a concluir que la referida paralización de la ejecución del acuerdo de reducción implica la postergación del pago del importe de la reducción al accionista respectivo. Es decir, la reducción de capital existiría como acto jurídico con plenos efectos legales, pero la acreencia que surge en favor del accionista a partir del acuerdo solo podría cancelarse luego de vencido el plazo sin oposiciones válidas o, de haberlas habido, luego de que el pago de los créditos respectivos haya sido cancelado o esté suficientemente garantizado.

Profundizando su análisis esta doctrina nos hace ver la otra cara de la moneda de los sistemas de protección que impiden los efectos del acuerdo de reducción de capital en tanto se atienda el interés de los acreedores, pues incide en los graves efectos que la paralización de la reducción durante el plazo legal de espera o hasta que se solucione la eventual oposición tiene para los accionistas involucrados en la reducción de capital, en cuanto frustra su expectativa de recibir el pago del importe de la reducción de capital hasta el transcurso de tal plazo o hasta que la sociedad cubra los requisitos necesarios en el caso de oposición, especialmente si la reducción "es la consecuencia de un previo acuerdo entre dos grupos de accionistas, en mérito al cual se ha decidido que uno (normalmente minoritario) abandone la compañía con restitución de aportaciones y el otro permanezca formando parte de la misma. La eventual oposición de los acreedores constituirá en estos supuestos un impedimento a la ejecución del acuerdo alcanzado entre los socios" 40 .

Continuando con su exposición, Pérez De la Cruz no pone en duda en ningún momento la existencia de la reducción de capital como acto desde el mismo momento en que se acuerda, con los efectos legales que ello supone respecto al socio que se retira de la sociedad, sino solo se pregunta si en tales situaciones "la sociedad estará obligada a la remoción del obstáculo que la oposición representa, por los cauces que señala el propio precepto (...) o si, a la vista del impedimento surgido, el acuerdo de reducción puede ser revocado, manteniendo el statu quo existente antes de la adopción". Agrega el autor que las posibles respuestas a esta interrogante "son tres: $a$ ) mantener que la eficacia

artículos 334 y 337 de la Ley de Sociedades de Capital, por lo que sus comentarios son plenamente aplicables para ambas leyes.

40 PÉREZ DE LA CRUZ BLANCO, Antonio. Comentario al Régimen de las Sociedades Mercantiles. Dirigido por Rodrigo URIA, Aurelio MENENDEZ y Manuel OLIVENCIA, Editorial Civitas S.A., Tomo VII, Modificación de Estatutos en la Sociedad Anónima y Reducción de Capital, Volumen N³, La Reducción de Capital, 1995, p. 110. 
del acuerdo de reducción está condicionada a que los acreedores presten su aquiescencia y que, a la vista de la actitud que por ellos se adopte, la Junta general de la sociedad está facultada para apartarse de su decisión y revocar, mediante nuevo acuerdo, el adoptado en orden a la reducción; b) sostener, como variante de lo que acabamos de decir, que el acuerdo por el que se revoque la decisión de reducir el capital queda sometido, amén de al consentimiento mayoritario de la Junta general, a la decisión, igualmente mayoritaria, de una asamblea especial de los titulares de las acciones que van a verse afectadas por la revocación de la reducción; y, finalmente, c) conceptuar que una vez adoptado válidamente el acuerdo de reducción nace para los afectados por éste un derecho individual e indisponible por la mayoría para obtener la restitución de las aportaciones del que no pueden ser privados sin su individual consentimiento"41.

La respuesta correcta para Pérez De la Cruz es la tercera. Es decir, "la válida adopción del acuerdo de reducción hace surgir en favor de los accionistas afectados por la medida un derecho de crédito frente a la sociedad por la suma que ha de abonárseles", agregando que ese derecho de crédito

"en modo alguno, hay que considerarlo sometido a la condición suspensiva de que los acreedores no formulen oposición, ya que ésta, de existir, no tiene otro objetivo ni más alcance que el de exigir la adopción de determinadas medidas complementarias por parte de la sociedad, pero nunca interfiere en la ejecución del acuerdo, una vez que estas medidas se hayan adoptado (...) A nuestro juicio, este derecho individual del socio afectado por la reducción relativo a la liquidación de su cuota, en el plazo y por la cuantía que en el acuerdo se señale, resulta indisponible por las mayorías, ya sean de la Junta general, ya de las Asambleas especiales que previamente se hubieran celebrado" 42 .

Como se ve, para esta doctrina el hecho de que la reducción de capital no pueda "llevarse a efecto" en tanto transcurra el plazo de espera legal luego de la publicación del aviso, o se pague o se garantice la deuda de existir oposición de los acreedores, en ningún caso la lleva a cuestionar la existencia y plena aplicación del acuerdo de reducción desde el momento de su adopción, en cuanto el mismo supone la disminución del capital y el apartamiento del socio afectado de la sociedad. Lo único que sucede con el plazo de espera legal o la oposición, de haberla, es, según este autor, que el pago del crédito que surge

41 Ibid., 1995, pp. 110 y 111.

42 PÉREZ DE LA CRUZ BLANCO, Antonio. "Comentario al Régimen de las Sociedades Mercantiles". Dirigido por Rodrigo URIA, Aurelio MENENDEZ y Manuel OLIVENCIA, Editorial Civitas S.A., Tomo VII, Modificación de Estatutos en la Sociedad Anónima y Reducción de Capital, Volumen N³, La Reducción de Capital, 1995, pp. 111 y 112. 
en favor del socio afectado al adoptarse el acuerdo de reducción de capital se suspende en aplicación de la ley, pero, aun así, siendo un derecho individual e indisponible, puede ser inmediatamente exigido por éste a la sociedad, la que se encontrará en tal caso en la obligación de apresurar todas las medidas que sean necesarias (garantía o pago a los acreedores opuestos) para efectuar el pago al socio afectado por la reducción lo antes posible.

Es clara la posición de Pérez De la Cruz en relación a que el hecho de que la reducción de capital no pueda "llevarse a efecto" durante el plazo del mes en que los acreedores pueden oponerse, o hasta que se solucione la oposición, de haberla, según disponen la Ley de Sociedades Anónimas de 1989 y la Ley de Sociedades de Capital de 2010, en ningún caso supone que el acuerdo respectivo quede sometido por mérito de la ley a una condición suspensiva que implique que el socio afectado por la reducción de capital continúe siendo socio en tanto la situación de los acreedores opuestos se resuelva. Este autor lo dice expresamente cuando apunta que el derecho de crédito que surge en favor del socio afectado por la reducción de capital "en modo alguno, hay que considerarlo sometido a la condición suspensiva de que los acreedores no formulen oposición".

Además, cuando el autor que comentamos se pronuncia en el sentido de que la respuesta correcta ante la interrogante de lo que sucede en los casos de oposición es que apenas adoptado el acuerdo de reducción de capital surge en favor de los socios afectados con el mismo un derecho de crédito contra la sociedad de naturaleza indisponible, descarta las otras alternativas de respuesta que este mismo autor se había planteado, una de las cuales era sostener que "la eficacia del acuerdo de reducción está condicionada" de la manera que anota en su texto y que ya hemos visto. En efecto, si, conforme señala este autor, apenas adoptado el acuerdo de reducción de capital surge en favor del socio afectado "un derecho de crédito frente a la sociedad por la suma que ha de abonársele", es claro que el acuerdo empieza a surtir efectos desde ese momento, pues de no ser así (por estar sujeto el acuerdo a una condición suspensiva en tanto venza el plazo de oposición, por ejemplo), no existiría aun crédito alguno del socio afectado que reclamar.

Como se puede ver de todos los comentarios anteriores, la doctrina española no es categórica en un sentido $u$ otro, pues hay opiniones indicando que no existe la reducción de capital como acto, y consecuentemente no produce ningún efecto legal, por lo menos hasta que venza el plazo de oposición de los acreedores, pero también en el sentido de que adoptado el acuerdo de reducción de capital el mismo empieza a surtir efectos desde ese momento, y que lo único que implica ese derecho de oposición es una postergación en el 
pago del crédito que ya surgió en favor del socio afectado con la reducción de capital en tanto no venza el plazo respectivo o se solucione la oposición formulada.

\section{Tratamiento de la Protección de Acreedores en la Reducción del Capital en la Legislación Peruana}

Como ya hemos dicho, los artículos 218 y 219 de la LGS establecen que la reducción de capital con devolución de aportes "sólo puede llevarse a cabo" luego de 30 días de la última publicación del aviso respectivo, período dentro del cual los acreedores de la sociedad tienen derecho de oponerse "a la ejecución del acuerdo de reducción del capital".

En primer lugar, se puede ver de estas normas que en el Perú se ha optado por una protección en favor de los acreedores en los casos de reducción de capital preventiva o 'a priori'. Junto con ello, sin embargo, cabe preguntarse si estas normas en realidad impiden proceder con el acto mismo de la reducción de capital, por lo menos, hasta transcurrido el plazo de 30 días mencionado por el artículo 218 de la LGS antes referido, o si lo que estas normas buscan es simplemente impedir la salida de la sociedad de los recursos equivalentes al importe de la reducción del capital en tanto transcurra este plazo.

Si fuera lo primero, habrá que entender que la reducción de capital con devolución de aportes está sujeta a una condición suspensiva en virtud de la cual la misma no surte efectos en tanto (i) transcurran los 30 días posteriores al último aviso mencionado en el segundo párrafo del artículo 218 de la LGS, (ii) se resuelva la respectiva oposición interpuesta en ese plazo o (iii) la sociedad tome las medidas necesarias para proseguir con la ejecución de la reducción de capital a pesar de la oposición. Como se entiende, esto implicará que el socio afectado con la reducción ${ }^{43}$ se mantenga en su condición de tal en tanto, dependiendo de las circunstancias, transcurra el plazo que finalmente se aplique de acuerdo a lo señalado anteriormente ${ }^{44}$.

En la segunda posibilidad de interpretación, más bien, la reducción del capital

43 Al igual que PÉREZ DE LA CRUZ, para hacer más claro el análisis solo nos referiremos al caso de la reducción de capital que afecta a uno de los socios y no a todos a prorrata de su participación, como es el caso general, pues en esta segunda hipótesis no se percibe con igual intensidad la problemática detrás del caso, dado que al margen de un retraso en el pago del importe de la reducción, a todos los accionistas les dará lo mismo conservar su condición de tales durante el proceso de la oposición o no.

44 Otra posibilidad de interpretación dentro de esta primera posición es que la reducción de capital exista y produzca efectos en tanto no se de una oposición de algún acreedor y que, de producirse, esta situación se revierta, regresando el accionista a su condición de socio. Esta opción creemos que no se condice decididamente con el texto del artículo, además de ser la menos técnica y deseable, por lo que no la consideraremos en el análisis. 
existe como acto y genera sus efectos al interior de la sociedad desde el momento del acuerdo mismo, aunque el importe de la reducción sólo pueda ser pagado al accionista respectivo, dependiendo, (i) luego de los 30 días que menciona el segundo párrafo del artículo 218 de la LGS, (ii) una vez que se resuelva la respectiva oposición interpuesta en ese plazo, o (iii) una vez que la sociedad tome las medidas necesarias para proseguir con la ejecución de la reducción de capital a pesar de la oposición ${ }^{45}$.

La doctrina nacional más representativa parece ser ambivalente sobre el tema. En efecto, comentando el artículo 218 de nuestra ley, Elías Laroza ${ }^{46}$ anota que el hecho de que la reducción de capital solo pueda llevarse a cabo luego de los 30 días del último aviso, "tiene por objeto que la operación no pueda empezar a ejecutarse durante el plazo que tienen los acreedores de la sociedad para ejercitar el derecho de oposición contemplado en el artículo 219", con lo cual parecería claro que según este autor no existe el acto mismo de reducción de capital sino hasta después de transcurrido ese plazo.

Más adelante, sin embargo, comentando el artículo 219 de la LGS, esta misma doctrina ${ }^{47}$ anota que "el derecho de oposición versa con respecto a la ejecución del acuerdo y no con relación al acuerdo mismo", con lo cual da la impresión de que pensara que la oposición no afecta el "acuerdo mismo", que entonces, agregamos nosotros, tendría efectos desde su adopción.

En realidad, sin embargo, nos parece que no cabría extraer una posición definitiva de los comentarios que incluye esta doctrina en relación a los artículos 218 y 219 de la LGS, porque parece que tales comentarios no están destinados a resolver el problema que ahora nos planteamos sino a explicar aspectos generales de estas normas.

Entrando en materia, entonces, diremos que ya se ha visto la función de garantía que, si bien discutida, cumple el capital respecto de los acreedores de la sociedad. Si la verdadera garantía es el monto del capital, no tendría sentido, dirían los que defienden la tesis de que no hay reducción de capital sino hasta transcurridos los 30 días posteriores al último aviso, que una norma que busca la protección de los acreedores admita que se afecte la cuenta capital en tanto, por lo menos, no hayan transcurrido los 30 días posteriores al último aviso luego de la reducción.

Más todavía, me atrevería a decir que lo que el legislador de la LGS quiso en

45 Para facilidad de la exposición, de estas tres posibilidades solo nos referiremos en adelante al transcurso de los 30 días.

46 ELÍAS LAROZA, Enrique. Derecho Societario Peruano, Ley General de Sociedades. Edición puesta al día por el Estudio Rodrigo, Elías \& Medrano. Lima: Gaceta Jurídica, 2015, Tomo I, p. 765.

47 Ibid., p. 768. 
su momento fue en efecto consagrar la teoría más extrema de protección ' $a$ priori' de los acreedores en los casos de reducción de capital, es decir sujetar el acuerdo de reducción de capital a una condición suspensiva conforme a la cual el acuerdo de reducción de capital no produce ningún efecto sino, en el mejor de los casos, hasta transcurridos los 30 días posteriores al último aviso.

Y una primera lectura del segundo párrafo del artículo 218 de la LGS parecería reafirmar que la conclusión correcta en este caso es esa. En efecto, lo que este segundo párrafo indica es que cuando la reducción de capital importe devolución de aportes, "ella" (la reducción se entiende) solo "puede llevarse a cabo luego de treinta días de la última publicación del aviso a que se refiere el artículo anterior". Y si la reducción de capital solo puede "llevarse a cabo" luego de los 30 días del último aviso, no hay que transitar mucho dentro de esta interpretación para concluir que no habría reducción, como acto, sino en el mejor de los casos hasta transcurrido ese plazo.

Sin embargo, ya sabemos que lo que el legislador pueda haber querido cuando redacta una norma, no definirá necesariamente la interpretación correcta de la misma una vez que la misma se promulga. Y creo que esto se da en el presente caso, pues hay otras normas en estos mismos artículos 218 y 219 de la LGS, así como otras consideraciones, que ponen en tela de juicio la conclusión anterior y que más bien nos persuaden de la conclusión contraria.

Si la interpretación correcta del segundo párrafo del artículo 218 de la LGS fuera en efecto que no hay reducción de capital en tanto transcurra el plazo de 30 días que esa norma menciona, tendríamos que entender que de procederse prematuramente con la ejecución de la reducción antes de vencido ese plazo, la misma no podría surtir efectos legales, y sería un acto jurídico ineficaz o nulo. Sin embargo, si nos detenemos en lo que dice el tercer párrafo de esta norma ese no parece ser el caso, pues, conforme al mismo, si "se efectúa la devolución [...] antes del vencimiento del referido plazo, dicha entrega no será oponible al acreedor y los directores serán solidariamente responsables con la sociedad frente al acreedor que ejerce el derecho de oposición" respectivo.

Como se puede ver, este tercer párrafo del artículo bajo comentario no declara ineficaz o nula la reducción de capital y la consiguiente ejecución de sus efectos (el pago al socio) antes de transcurrido el plazo de 30 días, sino solo se preocupa de plantear un remedio económico para la situación disponiendo que el reembolso efectuado "no será oponible al acreedor" opuesto, y que los directores serán solidariamente responsables con la sociedad por el pago del crédito de ese acreedor.

En nuestra opinión esta norma nos revela la correcta interpretación que debe 
darse al segundo párrafo del artículo 218 de la LGS, que señala que "cuando la reducción de capital importe devolución de aportes [...] ella solo puede llevarse a cabo luego" de los 30 días del último aviso al que esta norma se refiere. Lo que esta norma limita ("solo puede llevarse a cabo"), pensamos, no es la reducción de capital en sus aspectos materiales, es decir el acto jurídico de disminución del capital y exclusión del socio afectado de su condición de socio, que en consecuencia surte sus efectos propios desde el acuerdo mismo, por lo menos internamente, sino solamente el pago del importe de la reducción al referido socio afectado.

En esta misma línea repasemos ahora el último párrafo del artículo 218 que indica que el reembolso prematuro al socio afectado con la reducción de capital "no será oponible al acreedor" opuesto ${ }^{48}$. Si eso es así, por interpretación a contrario, tenemos que este acto sí surte efectos (es oponible) en todos los otros casos, de manera que, por declaración de la ley, tenemos un acto que surte sus efectos propios, es decir, la disminución de la "garantía" que suponía el importe del capital previo a la reducción para todos los acreedores de la sociedad salvo para el respectivo acreedor opuesto, al cual (solo a él entonces) no le "será oponible".

Y esto último nos reafirma en que la conclusión correcta es la que defendemos. En efecto, el hecho de que la reducción de capital no sea "oponible" solo al acreedor opuesto implica (la otra cara de la moneda) que necesariamente el acto tiene que existir al interior de la sociedad desde su aprobación. En efecto, solo no puede ser "oponible" en un único caso particular, aquello que tiene existencia legal plena en todos los otros casos.

Otra razón importante que nos persuade en el sentido de que la reducción del capital sí existe como acto y genera sus efectos de fondo al interior de la sociedad desde el momento del acuerdo mismo, y que a lo único a lo que apuntan los artículos 218 y 219 de la LGS es a impedir que el importe de la reducción sea pagado al accionista respectivo antes de los 30 días que esas normas mencionan, es el texto del último párrafo del referido artículo 219, que señala que si hay oposición de algún acreedor la misma "se tramita por el proceso sumarísimo, suspendiéndose la ejecución del acuerdo hasta que la sociedad pague los créditos o los garantice".

Obsérvese que, conforme a esta norma, la "suspensión" ocurre solo cuando se

48 Por más que no lo diga expresamente este último párrafo del artículo 218 de la LGS, resulta claro que esta es la lectura correcta de esa norma al amparo de lo que se indica en el resto de ese último párrafo que precisa que la responsabilidad solidaria de los directores en los casos de ejecución prematura de la reducción de capital es "frente al acreedor que ejerce el derecho de oposición". 
da la oposición. Esta norma no indica que en el ínterin el acuerdo no haya producido efectos ${ }^{49}$. Es decir, no estamos ante un acto (la reducción de capital con devolución de aportes) sujeto desde su aprobación a una condición suspensiva en virtud de la cual el mismo no haya existido ni surtido efectos en tanto hayan transcurrido los 30 días que venimos mencionando, sino ante un acto jurídico que, tanto existe desde su aprobación, que la ley dispone la "suspensión" de su ejecución solo después de producida una eventual oposición.

De lo anterior resulta, ratificando nuestra conclusión respecto de la correcta interpretación del artículo 218 de la LGS, que, si el acto existe y continúa existiendo luego de la oposición ${ }^{50}$, la suspensión de la "ejecución" que esa norma menciona solo podrá estar referida al pago del importe de la reducción al socio afectado y no a la reducción de capital, que necesariamente habrá producido, y continuará produciendo, sus efectos de fondo, vale decir la disminución del capital y la separación del socio afectado. Vemos la reducción de capital como un acto complejo que se completa con el pago del importe de la reducción de capital al respectivo socio afectado, por lo que perfectamente podemos diferenciar lo que son los efectos materiales o de fondo de la reducción, del pago que completa la ejecución del acto, y así, será posible interpretar que la suspensión derivada de la oposición formulada por algún acreedor puede estar referida solo al pago al socio respectivo y no a los otros aspectos del acto.

Si bien es obvio, también hay que resaltar ahora que la reducción de capital no es un acto formal, independientemente de que para su inscripción en el Registro Público se requiera elevarlo a escritura pública51, con lo cual está en

49 Y acá recuérdese que ya hemos visto que, de la debida concordancia del segundo y tercer párrafos del artículo 218 de LGS, el hecho de que, conforme a esa norma, la reducción no puede llevarse a cabo en tanto transcurra, en el mejor de los casos, el plazo de oposición debe interpretarse que está referido a una postergación del pago del importe de la reducción y no a que los otros efectos materiales del acto no se hayan producido ya.

50 Pues la norma nunca habla de una revocación o reversión de la reducción de capital luego de la "suspensión".

51 Si bien es cierto que conforme a los artículos 5 y 215 de la LGS la reducción de capital debe constar en escritura pública e inscribirse en el Registro, el artículo 144 del Código civil ya ha aclarado que cuando "la ley impone una formalidad y no sanciona con nulidad su inobservancia, constituye solo un medio de prueba de la existencia del acto".

Además, comentando el artículo 84 de la Ley de Sociedades Anónimas española de 1951, GARRIGUES y URÍA, que, debidamente concordado con el artículo 97 de esa ley, tiene una redacción similar a nuestro artículo 215 de la LGS, en cuanto a la formalidad exigida," señalan que "la inscripción en el Registro no tiene en este caso carácter constitutivo", agregando, además, que lo único que hace la ley cuando señala que la reducción de capital debe constar en escritura pública "es establecer el principio general [...] de exigencia de escritura pública en todo caso de modificación estatutaria".

GARRIGUES, Joaquín y URÍA, Rodrigo. Comentarios a la Ley de Sociedades Anónimas. Madrid: Imprenta Aguirre, Tercera Edición, Tomo II, 1976, p. 239. 
posibilidad de producir sus efectos materiales propios, es decir, la disminución del capital y la exclusión del socio de su condición de tal, con el acuerdo, independientemente de la postergación del pago al socio afectado en tanto se atienda el interés de los acreedores conforme a lo que las normas que estamos analizando señalan.

Esta última consideración, y todo lo que ya hemos dicho sobre la correcta interpretación de los artículos 218 y 219 de la LGS, nos permiten afirmar que lo que tales normas buscan no es que la reducción de capital no surta sus efectos de fondo en tanto transcurran los 30 días que esos artículos mencionan, sino solo impedir el pago del importe de la reducción al socio afectado hasta que transcurra ese plazo.

Alguien podrá decir acá que estamos basando nuestras conclusiones en estirar de manera extrema cierta falta de concordancia de las normas aplicables, pero que en esencia es claro que si la reducción de capital no "puede llevarse a cabo", en el mejor de los casos, hasta transcurridos los referidos 30 días, y la oposición produce la "suspensión" del acto, no debería existir duda de que, en concordancia con los sistemas más tradicionales de protección de acreedores, también nuestra legislación consagra una implícita condición suspensiva del acuerdo desde su aprobación y punto.

Pero, en concordancia con lo que hemos dicho sobre la vida propia de las normas luego de promulgadas, por rigurosidad académica no podemos simplemente obviar las otras disposiciones de la ley que desmienten esa conclusión y más bien nos llevan a la orilla contraria, pues ¿cómo puede haber un acuerdo que supuestamente no surte efectos desde su aprobación, si la ley admite su incumplimiento sin penalizar el acto con ineficacia o nulidad sino con una consecuencia económica para el infractor? $\mathrm{O}$, ¿cómo lo puede haber si la propia ley acepta que el acuerdo de reducción de capital no es oponible para el acreedor que se oponga pero sí para el resto, o que la suspensión de los efectos solo ocurre si hay oposición y no antes?

Con tranquilidad de conciencia, entonces, defendemos nuestro punto de vista, independientemente incluso de que esa pueda no haber sido la intención del legislador al promulgar la norma. Y acá, profundizando el análisis, nos da tranquilidad también comprobar que nuestra posición, no solo refleja lo que creemos es la correcta interpretación de las normas, sino lo lógico y deseable en este campo.

En efecto, ya Pérez de la Cruz ${ }^{52}$ nos ha hecho ver la grave afectación a la vida

52 PÉREZ DE LA CRUZ BLANCO, Antonio. "Comentario al Régimen de las Sociedades Mercantiles". Dirigido por Rodrigo URIA, Aurelio MENENDEZ y Manuel OLIVENCIA, 
social que podría suponer el hecho de que una eventual oposición de los acreedores a una reducción de capital con devolución de aportes traiga como consecuencia soluciones que nos lleven a aceptar hasta la posible revocación del acuerdo ya adoptado.

Sin embargo, nosotros vemos grave afectación a la vida social incluso dentro de la tesis menos extrema de que la reducción de capital con devolución de aportes está automáticamente sujeta a una condición suspensiva en virtud de la cual la misma no surta efectos, en el mejor de los casos, en tanto transcurran los 30 días posteriores al último aviso. Y acá, para tratar los casos más reveladores, hablemos en primer lugar de las sociedades colectivas y la eventual aplicación de la regla de protección de acreedores que venimos tratando en el caso de una reducción de capital en esas empresas.

Es cierto que a ese respecto Villacorta ${ }^{53}$ nos hace ver que en el caso de las sociedades colectivas la verdadera garantía de los acreedores es la responsabilidad ilimitada de los socios en relación a las operaciones de la empresa, antes que el capital mismo, como sucede en las sociedades de responsabilidad limitada, con lo cual podría suponerse que la devolución de capital a sus socios no es relevante $\mathrm{y}$, entonces, tampoco las reglas de protección de acreedores para esos casos que venimos comentando. Sin embargo, el Reglamento del Registro de Sociedades ${ }^{54}$ parece no dejar duda respecto a que sí son aplicables a las sociedades colectivas los artículos 218 y 219 de la LGS en los aspectos vinculados a la protección de acreedores que nos interesan ahora.

Siendo así, habrá que resaltar que si la interpretación correcta de estas últimas normas de la LGS fuera en efecto que no hay reducción de capital, como acto con efectos jurídicos válidos, sino hasta transcurrido el plazo de 30 días que las mismas establecen o, peor aún, hasta que se resuelva la eventual oposición de algún acreedor o la sociedad preste garantía suficiente, tendríamos que un socio que se ha separado voluntariamente de una sociedad colectiva se mantendría con su participación intacta en el capital social luego de ejercido

Tomo VII Modificación de Estatutos en la Sociedad Anónima y Reducción de Capital, Volumen N³, La Reducción de Capital, Editorial Civitas S.A., 1995, pp. 93, 110 y 111.

53 VILLACORTA HERNÁNDEZ, Miguel Ángel. "Reducción De Capital: Aspectos Mercantiles y Contables". En Revista Del CES Felipe II, N¹0, 2009.

54 Conforme A La Debida Interpretación Concordada De Los Artículos 72, 83, 94 y 102 De Ese Reglamento, "Son Aplicables A La Inscripciones Correspondientes A Las Sociedades Colectivas, Las Disposiciones De Este Reglamento Para Las Sociedades Comerciales De Responsabilidad Limitada" y "Las Sociedades Anónimas", Incluyendo El Artículo 72, Conforme Al Cual En La Escritura Pública De Reducción De Capital "Deberá Insertarse, O Acompañarse A La misma, las publicaciones del aviso de reducción y la certificación del gerente general de que la sociedad no ha sido emplazada judicialmente por los acreedores, oponiéndose a la reducción". 
válidamente su derecho. Y si eso es así, los acreedores de la misma podrían entender que el mismo sigue respondiendo frente a terceros, sin responsabilidad limitada, por las operaciones de la sociedad celebradas luego de su retiro.

¿Sería acaso esta última una consecuencia lógica o deseable de las disposiciones contenidas en los artículos 218 y 219 de la LGS? La respuesta obvia es que no. $Y$ en realidad, como ya hemos dicho, la correcta interpretación de los artículos 218 y 219 de la LGS no nos lleva a esa interpretación equivocada, a nuestro modo de ver.

La correcta interpretación de esas normas en nuestra opinión, repetimos, es que cuando el artículo 218 de la LGS menciona que la reducción de capital con devolución de aportes a los accionistas "solo puede llevarse a cabo" luego de transcurridos 30 días desde la última publicación, o cuando el artículo 219 de esa misma ley señala que las eventuales oposiciones de los acreedores a la reducción de capital originan la suspensión de "la ejecución del acuerdo", solo se pretende que el importe de la respectiva reducción de capital no se restituya al socio afectado hasta transcurrido ese plazo o solucionada la oposición, mas no que el referido socio mantenga su participación en el capital, con las graves consecuencias que ello podría suponer en un caso como el planteado.

Pero avancemos más, imaginemos ahora no el caso de una separación voluntaria sino el de una exclusión del socio por causal aprobada válidamente por la junta respectiva. ¿Sería lógico y deseable entender que este socio mantiene su condición de tal a pesar de la exclusión porque hay posiciones según las cuales no hay reducción de capital como acto con efectos jurídicos válidos sino hasta transcurrido el plazo de 30 días de ley o solucionada la eventual oposición de algún acreedor? Sin perjuicio de que pensamos que esta no es la interpretación legal correcta, es claro nuevamente que la respuesta obvia es que esto no sería lógico ni deseable.

Sería absurdo pensar que la sociedad, luego de acordada válidamente la exclusión de un socio por causal, está obligada a seguir reconociéndole derechos de tal.

Ahora bien, podría sostenerse que una interpretación de los artículos 218 y 219 de la LGS como la que defendemos en estas líneas podría perjudicar a los socios afectados con la reducción de capital, que no solo se demoran en percibir el reintegro de su participación social, en el mejor de los casos hasta transcurridos los 30 días que estas normas mencionan, sino que durante ese lapso no "se benefician" de su condición de socios, saltando de allí a la conclusión de que la debieran mantener en tanto se les efectúa ese reintegro y 
que esa es en consecuencia la interpretación correcta de los artículos 218 y 219 recién mencionados.

En primer lugar, ya hemos visto que hacer una generalización sobre los eventuales beneficios de mantener la condición de socio de una sociedad después del acuerdo de reducción de capital no cabe. Claramente es lo contrario en ciertas situaciones, como la de las sociedades colectivas por ejemplo.

Tampoco cabe hacer una generalización en el sentido de que el socio afectado con la reducción de capital efectivamente "desea" mantener su condición de tal durante el lapso en que trascurre el plazo de 30 días de ley o, peor aún, durante el lapso que demore solucionar la eventual oposición de algún acreedor. Puede perfectamente ser lo contrario (claramente ya se perdió el affectio societatis si se está llegando a la instancia de la reducción de capital por retiro de un socio), por lo que tampoco cabe concluir que, como regla general, es lo que le conviene al socio afectado con una reducción de capital, o lo que éste quiere.

Al adoptarse el acuerdo de reducción de capital, tanto la sociedad como el socio han manifestado indudablemente su voluntad en el sentido de que ya no desean que el socio afectado continúe siendo socio de la sociedad. Si se deseara otra cosa, como que el socio mantenga su condición de tal en tanto ocurra el reembolso de su participación, podría contemplarse así en el acuerdo ${ }^{55}$, sin necesidad de que una interpretación equivocada de las normas aplicables obligue a esta solución en todos los casos, incluso en los más absurdos, al margen de lo que las partes verdaderamente desean.

Sin embargo, a pesar de que lo anterior es cierto, también es cierto que el socio afectado sufre perjuicio por la demora que existe en la devolución de su participación luego de la reducción de capital en aplicación de las normas de protección de acreedores que comentamos. Y lo que debemos analizar a raíz de esto, entonces, es si los mecanismos usuales para compensar demoras en el pago son suficientes para solucionar este problema, sin necesidad de obligar a la sociedad y al socio a mantener un statu quo que justamente han querido cambiar al acordar la reducción de capital respectiva.

Para esto, debemos empezar por dilucidar si el crédito que surge para el socio por el importe de su participación social al momento en que se adopta el

55 Podría ser el caso de una reducción de capital en que las partes no estén seguras de ir adelante si se presentan oposiciones de acreedores $\mathrm{u}$ oposiciones que superen un determinado monto. En ese caso, las partes podrían decidir en el acuerdo condicionar la efectividad del acto a esta situación, de manera que el mismo no surta efectos antes de que la oposición de los acreedores sea resuelta. 
acuerdo de reducción de capital, es exigible por el mismo inmediatamente o no. Si lo fuera, el socio afectado con la reducción de capital tendría la posibilidad de exigir a la sociedad que tome las medidas que sean necesarias para proceder a la brevedad con el pago del crédito que surge en su favor luego de la reducción de capital (garantías en favor de los acreedores afectados, por ejemplo). Si la sociedad no cumpliera, podrá constituirlo en mora, con las consecuencias y penalidades que ello supone en protección del pago de su crédito.

Como ya hemos visto, el artículo 218 de la LGS establece que la reducción de capital que importe devolución de aportes a los socios "solo puede llevarse a cabo luego de treinta días de la última publicación del aviso" correspondiente. El texto de esta norma, a nuestro modo de ver, revela que el crédito que surge en favor del socio afectado por la reducción de capital al aprobarse el respectivo acuerdo de reducción de capital no es un crédito exigible en tanto transcurra el plazo de 30 días que esa norma menciona.

En la medida en que, en una situación normal, la sociedad no tendrá forma de saber si algún acreedor efectivamente se opondrá a la reducción de capital dentro de ese plazo de 30 días, creemos que sería extremo sostener que la sociedad podría ser intimada por ese socio para tomar alguna acción que permita pagar su crédito (el proveniente de la reducción de capital) inmediatamente. Durante ese plazo inicial de 30 días, entonces, el socio afectado con la reducción de capital será titular de un crédito efectivo, sí, pero cuyo pago estará sujeto a un plazo suspensivo establecido por la ley.

Situación distinta ocurre, sin embargo, una vez vencido ese plazo inicial de 30 días. Esto es absolutamente obvio si no hay oposición de acreedores formulada en ese plazo. En esta situación, desde luego, el crédito originado por la reducción de capital se vuelve exigible y la sociedad se encontrará obligada a su cancelación al respectivo socio de manera inmediata. Si no lo hace el socio afectado podrá hacer valer sus derechos constituyendo en mora a la sociedad e interponiendo las acciones de cobro que puedan corresponder.

En nuestra opinión, el crédito del socio afectado con la reducción de capital también se vuelve exigible transcurridos los 30 días a que venimos haciendo referencia, por más de que durante ese plazo algún acreedor se haya opuesto a la reducción. En efecto, ya hemos visto que el artículo 219 de la LGS establece que si hay oposición se suspende "la ejecución del acuerdo hasta que la sociedad pague los créditos o los garantice a satisfacción del juez".

Como se ve entonces, cuando ya se venció el plazo de oposición de los acreedores sí existe posibilidad legítima y además razonable de hacer el pago 
al socio de manera inmediata si la sociedad adopta las medidas necesarias para ello, es decir, pagar los créditos del acreedor opuesto o garantizarlos.

Siendo así, creemos que luego de vencido el plazo inicial de 30 días el crédito que surge a favor del socio afectado por la reducción de capital se torna exigible, pues el socio no tiene por qué sufrir el perjuicio que significa una postergación en el pago de su crédito si está en manos de la sociedad adoptar las medidas necesarias para cumplir con su obligación. En ese sentido, el socio estará facultado para exigir a la sociedad que tome las acciones necesarias para el pago inmediato de su crédito (el proveniente de la reducción de capital) y si la sociedad no lo hace podrá hacer valer sus derechos constituyéndola en mora e interponiendo las acciones de cobro que puedan corresponder.

Y esto es exactamente a lo que se refería Pérez de la Cruz ${ }^{56}$ cuando, comentando la ley española, señalaba que, transcurrido el plazo del mes para el ejercicio del derecho de oposición, surge automáticamente un crédito contra la sociedad en favor del socio afectado que es indisponible por la mayoría, en el sentido de que está en el arbitrio del referido socio tomar todas las acciones que estén a su alcance para obligar a que la sociedad se ocupe de "remover el impedimento con la celeridad necesaria para que pueda" cumplirse con el pago con la celeridad necesaria, salvo que el propio acuerdo haya condicionado el pago de alguna manera.

En consecuencia y a nuestro modo de ver, entonces, los efectos materiales mismos del acuerdo de reducción de capital no se deben ver afectados porque la ley establece normas que eventualmente pueden hacer demorar el pago del importe correspondiente al socio afectado, pues los mecanismos usuales para compensar demoras en el pago deberían ser suficientes para solucionar este problema, sin necesidad de obligar a la sociedad y al socio a mantener un statu quo que justamente han querido cambiar de manera definitiva al acordar la reducción de capital respectiva.

De otro lado, no puede dejar de resaltarse también cómo el acreedor opuesto se encuentra perfectamente garantizado con la inamovilidad del importe de la reducción de capital, que es lo que le interesa, sin necesidad de que le deba preocupar que, para efectos internos de la sociedad, el accionista afectado sea excluido de la cuenta capital social57. Su posición como acreedor

56 PÉREZ DE LA CRUZ BLANCO, Antonio. Comentario al Régimen de las Sociedades Mercantiles. Dirigido por Rodrigo URIA, Aurelio MENENDEZ y Manuel OLIVENCIA, Editorial Civitas S.A., Tomo VII, Modificación de Estatutos en la Sociedad Anónima y Reducción de Capital, Volumen N³, La Reducción de Capital, 1995, pp. 111 y 112

57 De esto se da perfecta cuenta el legislador alemán, cuando el acento de sus normas de protección a acreedores en los casos de reducción de capital, no lo pone en la validez y 
quirografario ${ }^{58}$, que son los acreedores a quienes se permite la oposición en estos casos, no se ve afectada con los efectos materiales de la reducción de capital misma, sino con la eventual salida de caja de recursos que podría emplear la sociedad para pagar al acreedor opuesto de ser el caso. Y acá recordemos lo que nos dicen Pérez De La Cruz, Escribano Gamir y otros 59 sobre la relativa protección a los acreedores que implica la cifra capital frente al patrimonio social en su conjunto.

En consecuencia con todo lo anterior, lo que en nuestra opinión sucede en el caso general cuando se acuerda una reducción de capital con devolución de aportes en beneficio de un socio es que el acto, que no es un acto formal como ya hemos dicho60, produce sus efectos materiales propios, es decir, la disminución del capital y la exclusión del socio de su condición de tal, quedando pendiente únicamente el pago del importe respectivo hasta que haya transcurrido el plazo de 30 días de ley o hasta que se solucione la eventual oposición formulada por algún acreedor. El importe de la reducción de capital sale entonces de la cuenta capital y pasa a constituir un pasivo de la sociedad, el cual no podrá ser pagado al socio afectado en tanto se cumplan los requisitos de plazo de espera y demás que establecen los artículos 218 y 219 de la LGS.

Desde luego, el acuerdo podría establecer condiciones particulares para regular la reducción de capital, dentro de la autonomía de la voluntad de las partes. Así, podría contemplar expresamente mecanismos para resarcir al socio por la demora en el pago o establecer, más bien, que la demora en el pago producida por una eventual oposición de acreedores no implicará compensación alguna. El acuerdo incluso podría ser adoptado condicionando sus efectos al transcurso del plazo de 30 días o a la solución de eventuales oposiciones de acreedores, en cuyo caso, allí sí, la reducción de capital no ocurrirá sino hasta cumplida la condición. Obsérvese que todo ello, sin embargo, será por mérito de los pactos particulares a los que se sujete el acuerdo respectivo y no por mérito de la ley.

Es decir, dentro de la interpretación que defendemos los eventuales inconvenientes y particularidades que ocurran en la reducción de capital dependiendo de los distintos intereses en juego al momento del acuerdo, podrán ser básicamente solucionados por pactos entre las partes al adoptarse

efectos del acuerdo de reducción, sino en el pago del importe de la misma a los socios afectados.

58 El derecho de oposición no corresponde a los acreedores cuyo crédito se encuentra "adecuadamente garantizado".

59 Ver II. "Comentario General" en este artículo.

60 Ver Nota al Pie de Página 52. 
el mismo. En la interpretación contraria en cambio, en la que fatalmente la reducción de capital no entra en efecto sino hasta transcurridos los plazos de oposición o una vez solucionadas las oposiciones formuladas, no tenemos ese margen, por lo menos con la misma amplitud.

\section{Propuesta de Reforma}

Como se sabe, actualmente se viene trabajando una modificación de la actual LGS para remozarla luego de varios años de vigencia en que, a despecho de su bondad, pueden haberse revelado algunos errores que es necesario corregir o carencias a las que es necesario responder.

La coyuntura es importante entonces para poner este tema en debate y hacer una propuesta sobre lo que podría ser la norma que venga en relación al tratamiento de la protección de acreedores en casos de reducción de capital.

Al margen de la posición que se tenga sobre la correcta interpretación de los artículos 218 y 219 de la LGS, si persistimos en la redacción actual de las normas continuará el debate, y eso no es ciertamente lo deseable.

La investigación efectuada acerca de los distintos sistemas que en la legislación comparada se utilizan para proteger a los acreedores en casos de reducción de capital nos persuade en el sentido de que los sistemas de protección que no buscan impedir los efectos de la reducción de capital como acto desde el momento en que se acuerda, sino que solamente impiden el pago del importe de la reducción en tanto transcurra el plazo de oposición respectivo o se resuelva la oposición formulada, son los que mejor y más equilibradamente responden a los intereses, no solo de los acreedores, sino también de la sociedad y de los socios.

En efecto, si optáramos por esta alternativa tendríamos un sistema (i) adecuado para cubrir la exposición que les significa los acreedores una reducción de capital en la empresa deudora, tal como ha sido reconocido y probado en otras legislaciones, como la alemana o la portuguesa, (ii) aceptado por la legislación de la Comunidad Europea ${ }^{61}$ como un sistema de protección igual de eficaz para proteger el interés de los acreedores que los sistemas en que la reducción de capital no produce efectos, y (ii) que ampara lo que

61 Como se recuerda, el numeral 2 de la Directiva 1976/91/CE del Consejo de la Comunidad Europea establece que las legislaciones de los Estados miembros podrán optar por un sistema de protección de acreedores en que la reducción no produzca efectos, o en el "que no se podrá efectuar ningún pago en beneficio de accionistas, en tanto los acreedores no hubieran obtenido satisfacción o que un Tribunal hubiera decidido que no había lugar a acceder a su petición". Este tratamiento ha sido ratificado por la recientísima Directiva (UE) 2017/1132 del Parlamento Europeo y del Consejo. 
creemos debe ser la preocupación central en estos casos, es decir, que no haya pago a los socios como producto de la reducción de capital en tanto no se resuelvan sus eventuales reclamos, sin que los efectos internos de la reducción de capital (amortización de las respectivas acciones y cese de la condición de socio) deban verse perjudicados.

Otra razón importante que impulsa esta propuesta es que un sistema en que el acento no se ponga en impedir los efectos del acto sino en impedir el pago del importe de la reducción de capital tiene la flexibilidad necesaria para que las partes respondan mediante pactos privados a las particularidades de cada caso $^{62}$. Eso no cabría en un sistema en que la ley señalara que el acuerdo de reducción de capital no surtirá efectos sino hasta que transcurran los plazos de ley, pues un acuerdo privado no podría disponer que, por ejemplo, un socio ya no lo es, cuando la ley dice que sí lo es.

De otro lado, creemos que no estamos ciertamente preparados para soluciones más agresivas, como la propugnada ahora por la Comunidad Europea, exigiendo a los acreedores prueba del perjuicio como requisito necesario para obtener protección63, o para soluciones de tutela jurisdiccional previa consagradas por otras legislaciones, como la francesa o la inglesa.

En consecuencia, nuestra propuesta, que creemos garantiza por un lado una adecuada protección de los acreedores y por otro no disturba la vida social más allá de lo necesario, sería la siguiente:

a) Una vez adoptado el respectivo acuerdo de reducción de capital el importe afectado se deducirá de esa cuenta de manera que el respectivo acuerdo surta sus efectos legales, tanto en lo que respecta a la disminución del capital como a la exclusión del respectivo socio de su condición de tal.

b) A partir de la publicación de los avisos respectivos, de manera similar a lo que ocurre en nuestra ley actual, los acreedores gozarán de un plazo de oposición adecuado.

c) Durante el plazo de oposición o durante el plazo en que se resuelvan las oposiciones formuladas no se podrá pagar el importe de la reducción de capital a los socios, salvo que la sociedad pague o garantice adecuadamente el pago de todas sus deudas a los acreedores opuestos;

62 Recordemos, como ya hemos dicho, que si, por ejemplo, las partes verdaderamente desearan que la situación en el capital se mantenga inalterada en tanto transcurra el plazo de 30 días o se solucionen las eventuales oposiciones de acreedores, no habría ningún problema para que el acuerdo sea adoptado bajo esa condición.

63 Ver la Directiva 2006/68/CE del Parlamento Europeo y del Consejo sobre este tema. 
d) En los casos de oposición y luego de vencido el plazo para ello, los socios podrán accionar contra la sociedad para que la misma cancele o garantice a los acreedores opuestos sus créditos y así pueda pagar el importe de la reducción de capital a la brevedad posible;

e) Una vez acordada la reducción de capital y mientras queda congelado el pago de acuerdo a las reglas anteriores, el importe de la reducción de capital podrá acreditarse como un pasivo corriente de la sociedad en tanto se produce el pago.

Alternativamente, y como una solución de repente más próxima a nuestra tradición, y por eso tal vez mejor, pero novedosa, podría optarse legislativamente por disponer que el importe de la reducción se anote, no como un pasivo corriente de la sociedad, sino como una cuenta especial e intangible del patrimonio, distinta al capital, en tanto transcurren los plazos necesarios para el pago de su importe a los socios.

\section{Conclusiones}

Como consecuencia de todo lo anterior pensamos que:

a) Al margen de disquisiciones sobre la vigencia de la tesis tradicional que ve al capital como la única y verdadera garantía de los acreedores quirografarios para el pago de sus créditos y las teorías más modernas que cuestionan o complementan esto, nadie discute que siguen siendo universalmente necesarios los mecanismos de protección a los acreedores en casos de reducción de capital con devolución de aportes a los socios.

b) Los distintos sistemas de tutela de los acreedores en los casos de reducción de capital pueden clasificarse, en términos generales, en sistemas de protección 'a priori' y sistemas de protección 'a posteriori.

c) Según doctrina autorizada, el sistema 'a priori' básicamente consiste en dar a conocer a los acreedores el acuerdo o proyecto de reducción de capital, abriéndose a continuación un plazo durante el cual la operación se "suspende" y se insta a la sociedad deudora, básicamente, a prestar garantía o satisfacer los créditos pendientes.

Los sistemas 'a posteriori' pueden describirse de manera general como aquellos que aceptan la eficacia de la reducción de capital, con las consecuencias legales que supone ese acto, y centran la protección en otros aspectos básicamente relacionados a la postergación del pago del importe de la reducción de capital en tanto se garantice una protección adecuada para los acreedores. 
d) En una etapa más moderna de esta institución, se viene variando hacia sistemas que exigen a los acreedores que quieren ejercer su derecho de oposición una prueba del perjuicio que podría causarles la reducción de capital.

e) En la legislación de la Comunidad Europea se acepta, además, que son igualmente adecuados los sistemas de protección de acreedores que sujetan a condición suspensiva el acuerdo de reducción de capital hasta que se atienda el interés de los acreedores, y los sistemas en que se reconocen los efectos del acuerdo de reducción de capital y solo se posterga el pago del importe representado en el mismo.

f) Dentro de las legislaciones que optan por los sistemas de protección ' $a$ priori', como el español en el caso de las sociedades anónimas, la doctrina no es uniforme, pues hay opiniones en el sentido de que no existe la reducción de capital como acto por lo menos hasta que venza el plazo de oposición de los acreedores, pero también en el sentido de que adoptado el acuerdo de reducción de capital el mismo empieza a surtir efectos desde ese momento, y que lo único que implica ese derecho de oposición es una postergación en el pago del crédito que ya surgió en favor del socio afectado con la reducción de capital en tanto no venza el plazo respectivo o se solucione la oposición formulada.

g) Si bien creemos que el legislador de la LGS pretendió consagrar la teoría más tradicional de protección de acreedores, conforme a la cual el acuerdo de reducción de capital está sujeto a una condición suspensiva conforme a la cual no surte efectos sino, en el mejor de los casos, hasta transcurrido el plazo de oposición respectivo, las normas que finalmente han regulado la institución en los artículos 218 y 219 de esa ley nos llevan a la conclusión de que la reducción de capital con devolución de aportes en beneficio de uno de los socios produce sus efectos materiales al interior de la sociedad, es decir, la disminución de capital y la exclusión del socio de su condición de tal, desde el momento del acuerdo mismo, quedando únicamente pendiente el pago del importe respectivo al socio afectado hasta que haya transcurrido el plazo de 30 días de ley o hasta que se solucione la eventual oposición formulada por algún acreedor.

Adoptado el acuerdo, el importe de la reducción de capital sale de la cuenta capital y pasa a constituir un pasivo de la sociedad en favor del respectivo socio, el cual no podrá ser pagado a éste en tanto se cumplan los requisitos de plazo y demás recién mencionados. 
h) Luego de vencidos los 30 días del plazo de oposición, el socio afectado con la reducción de capital tiene el derecho de accionar contra la sociedad para obligar a la sociedad a adoptar las medidas necesarias para que se cumpla con el pago del importe respectivo a la brevedad posible.

i) Dentro de esta interpretación de la LGS, los eventuales inconvenientes y particularidades que ocurran en la reducción de capital, dependiendo de los distintos intereses en juego al momento del acuerdo, pueden, en uso de la autonomía de la voluntad, ser básicamente solucionados por pactos entre las partes al adoptarse el mismo.

Esta flexibilidad no es posible con el mismo grado de efectividad dentro de la interpretación contraria, conforme a la cual la reducción de capital no entra en efecto sino hasta transcurridos los plazos de oposición o una vez solucionadas las oposiciones formuladas.

j) Proponemos que en la próxima reforma de la LGS se considere un mecanismo de protección de acreedores que recoja lo planteado en el rubro III anterior. 